\title{
JAKA PRZYSZLOŚĆ \\ CZEKA MUZEUM ARCHEOLOGICZNE? \\ DYSKUSJA Z TEZAMI ZAWARTYMI \\ W KSIĄŻCE MONIKI STOBIECKIEJ: \\ NATURA ARTEFAKTU, KULTURA EKSPONATU. PROJEKT KRYTYCZNEGO MUZEUM ARCHEOLOGICZNEGO
}

\author{
WHAT IS THE FUTURE OF ARCHAEOLOGICAL MUSEUM? \\ A DISCUSSION WITH THESES PRESENTED \\ IN A BOOK BY MONIKA STOBIECKA: \\ NATURA ARTEFAKTU, KULTURA EKSPONATU. \\ PROJEKT KRYTYCZNEGO MUZEUM ARCHEOLOGICZNEGO
}

\author{
Michat Pawleta \\ https://orcid.org/0000-0002-0466-1901 \\ Wydział Archeologii Uniwersytetu im. Adama Mickiewicza \\ ul. Uniwersytetu Poznańskiego 7, 61-614 Poznań \\ mpawleta@amu.edu.p
}

\begin{abstract}
ABSTRAKT: This article is of polemical nature. It discusses main theses of the recently published book by Monika Stobiecka: Natura artefaktu, kultura eksponatu. Projekt krytycznego muzeum archeologicznego (2020). The book presents contemporary archaeology as a very innovative discipline striving for interdisciplinarity and extending beyond traditional research issues and borders. At the same, the authoress postulates a need to reorient archaeology and create a new type of archaeological museum, namely critical museum - "museum of life".
\end{abstract}

KEY WORDS: archaeological museum, archaeological theory, new materialism, artifacts, exhibits

W artykule podejmuję polemiczną i krytyczną dyskusję z tezami zawartymi w wydanej niedawno publikacji Moniki Stobieckiej Natura artefaktu, kultura eksponatu. Projekt krytycznego muzeum archeologicznego (Stobiecka, 2020). Autorka proponuje 
w niej krytyczny namysł nad przedmiotem badań archeologii, a także teorią i praktyką archeologii. Ukazuje w niej archeologię jako innowacyjną naukę dążącą do interdyscyplinarności, wykraczającą poza tradycyjną problematykę badawczą, otwartą na współczesny świat. Postuluje przy tym konieczność przeorientowania archeologii, aby przybrała formę symetrycznej i relacyjnej dyscypliny, scalającej w swej praktyce i interpretacji przeszłości podejście humanistyczne i archeometryczne. Sugeruje jednocześnie potrzebę wykreowania nowego typu muzeum archeologicznego - mianowicie muzeum krytycznego i „muzeum życia”.

\section{NATURA ARTEFAKTU, KULTURA EKSPONATU}

Książka Moniki Stobieckiej, absolwentki historii sztuki i archeologii, bazuje na dysertacji doktorskiej, przygotowanej przez nią na Wydziale „Artes Liberales” Uniwersytetu Warszawskiego. Liczy 358 stron, zawiera barwne ilustracje, które uzupełniają i wspierają narrację. Konstrukcja pracy opiera się na trzech częściach, mianowicie Artefakt, Eksponat oraz Artefakt jako eksponat, na które składa się łącznie dziesięć rozdziałów. Całość została opatrzona wprowadzeniem i zakończeniem.

Książka ma charakter interdyscyplinarny, lokując się na styku historii i teorii archeologii, historii sztuki oraz studiów muzealnych. Zawarte w niej rozważania skupiają się wokół trzech spajających je pojęć: artefaktu, eksponatu i strategii muzealnych, w celu ukazania translacji artefaktu w eksponat za pomocą teorii i metodologii archeologii (s. 38, sic!).

Problem badawczy, który przyświeca Autorce, to:

relacja muzeum i obowiązujących paradygmatów wobec nowych podejść i teorii w archeologii, a zarazem próba ukazania współzależności, związków i sprzężeń, jakie zachodzą pomiędzy akademią a muzeum. (s. 16)

Biorąc za przykład instytucję muzeum archeologicznego, proponuje ona projekt muzeum krytycznego, zmierzającego w stronę krytycznej instytucji, otwierającej się na intelektualną współczesność, mediującej różne teorie, innymi słowy muzeum, w którym istnieje nierozerwalność instytucji naukowych i dyskursów naukowych i które ilustruje paradygmatyczne zmiany w teoriach i negocjuje ich znaczenia (s. 15). W celu realizacji postawionego w książce celu, Autorka z powodzeniem aplikuje założenia tzw. Nowej Muzeologii i jej aktualne przełożenie na realia muzeum archeologicznego. Wskazuje tym samym, że jednym z głównych celów muzeum archeologicznego powinno być właśnie osiągnięcie statusu muzeum krytycznego, czyli wprowadzenie $\mathrm{w}$ jego przestrzeń takich narracji wystawienniczych, które $\mathrm{z}$ jednej strony zdolne byłyby do zmierzenia się z aktualnymi wyzwaniami współczesności, z drugiej zaś prezentowały najnowsze tendencje badawcze w archeologii (s. 16).

W pierwszej części publikacji Artefakt M. Stobiecka odnosi się do centralnego elementu badań i zainteresowań archeologów, mianowicie artefaktu, w tym artefaktu 
archeologicznego. Zajmuje się w nim jego definicją, w różnych ujęciach i propozycjach, którą stara się zredefiniować przy wykorzystaniu metody autoetnograficznej (s. 19), czyli skupionej na jej własnym doświadczeniu badawczym, które łączy następnie z szerszymi znaczeniami i założeniami. Odnosi się tu do obowiązujących we współczesnej archeologii paradygmatów, ujęć teoretycznych, definicji w naukach ścisłych czy praktyki konserwatorskiej. Proponuje ujmować artefakt nie w tradycyjnym i statycznym znaczeniu - jako przedmiot, rzecz będąca wytworem ludzkim, lecz w ujęciu czasownikowym - przez jego czynnościowy, sprawczy i działaniowy charakter (s. 20). Opozycyjne w stosunku do dominującego ujęcie pozwala jej zaś na ukazanie, jak artefakt staje się eksponatem (muzealnym). Na podstawie własnych obserwacji poczynionych podczas archeologicznych prac terenowych, obudowanych inspiracjami teoretycznymi nowego materializmu, proponuje osiem różnych oblicz artefaktu odnoszących się do jego różnych cech (rozdz. 2), z którymi mierzą się archeolodzy $\mathrm{w}$ trakcie jego odkrywania i eksplorowania. Jej zdaniem są one efektem działania czynników pozakulturowych i są to kolejno: fragment, zagadka, skrytość, biologia, kolor, dynamika, kontekst, ekstrakcja. Prowadzi ją to do finalnej redefinicji artefaktu, która brzmi następująco:

przedmiot zainteresowań archeologii charakteryzujący się niestałością, zdolnością do przemian, długim trwaniem, podatnością na czynniki zarówno wynikające z działalności człowieka, jak i niezależne od niego czynniki o charakterze biofizyko-chemicznym [...]. Artefakt nie jest przedmiotem, nie znajduje bowiem swojego pierwotnego zastosowania: nie powraca do dziejowej funkcji z przeszłości. Artefakt jest dowodem, śladem, świadectwem i źródłem. Artefakt jest długowieczną, dynamiczną materią operującą poza ludzką sprawczością. (s. 95-96)

W rozważaniach zamieszczonych w kolejnej części pracy zatytułowanej Eksponat Autorka zajmuje się problematyką obiektu centralnego dla muzeum, czyli eksponatu. Analizuje pod tym kątem cztery europejskie wystawy archeologiczne, zorganizowane lub zrekonstruowane w ostatnich dwóch dekadach, mianowicie: Sir John Soane's Museum w Londynie (rozdz. IV), Neues Museum w Berlinie (rozdz. V), Museo dell'Ara Pacis w Rzymie (rozdz. VI) oraz Acropolis Museum w Atenach (rozdz. VII). Wybiera z nich dwa lub trzy eksponaty bądź fragmenty wystaw, które poddaje analizie i interpretacji. Wybrane ekspozycje traktuje przy tym jako studia przypadku, które stanowią dla niej asumpt do refleksji nad rolą artefaktu jako eksponatu w przestrzeni muzeum archeologicznego oraz interesujące alternatywy wobec wiodących modeli eksponowania $\mathrm{w}$ archeologii. Stanowią one dla niej jednocześnie ilustracje następujących po sobie paradygmatów archeologicznych, w ramach których profilowane są wystawy (s. 18). Analizowane ekspozycje ilustrują kolejno: etap przednaukowej archeologii; początki akademickiej archeologii, gdy kształtowały się jej metody i aparat badawczy; etap współczesnej archeologii, obejmujący szerokie spektrum zagadnień, od badań nad archeologią i sztuką po perspektywy interdyscyplinarne, włączające m.in. badania archeobotaniczne; oraz aktualny obraz dyscypliny, w zakres zainteresowań 
której wchodzi rekonstruowanie artefaktów i wprowadzanie w przestrzeń wystawienniczą progresywnych technologii. Taki sposób uporządkowania narracji i wybór ilustrujących rozważania przykładów pozwalają ukazać Autorce muzeum archeologiczne jako swoisty dokument historii dyscypliny.

W trzeciej części pracy Artefakt jako eksponat Autorka prezentuje trzy strategie dla muzeów archeologicznych, do analizy których wprowadza własne kategorie interpretacyjne. $\mathrm{W}$ formułowaniu swoich autorskich projektów sięga głównie do dorobku przedstawicieli studiów nad archeologią cyfrową i wirtualną, badaczy zajmujących się wzajemnymi relacjami między archeologią a sztuką, a także reprezentantów archeologii symetrycznej oraz relacyjnej.

Pierwszym z nich jest projekt „archeologii protetycznej” (rozdz. 8), w którym odnosi się do rozpowszechnionej w ostatnich latach praktyki wprowadzania w przestrzeń muzealną nowych technologii multimedialnych. Autorka zwraca uwagę na doraźny charakter tego typu zabiegów, stwierdzając, że mogą i powinny one służyć przede wszystkim do animowania artefaktów czy uzupełniania ubytków w zabytkach. Przeciwstawia się zaś stanowczo „bezmyślnej aplikacji technologii w muzeach”.

Drugi z projektów „preposteryjna sztuka archeologii” (rozdz. 9) analizuje wzajemne relacje między sztuką a archeologią, a także zarysowuje potencjalną alternatywę w mediacjach sztuki archeologią oraz archeologii sztuką. M. Stobiecka, nawiązując do koncepcji reprezentacji i doświadczenia historycznego Franklina Ankersmita oraz preposteryjnej historii sztuki holenderskiej krytyczki i teoretyczki kultury Mieke Bal, proponuje, że w ramach preposteryjnej sztuki archeologii zarówno artefakty, jak i dzieła sztuki mogą potraktować jako „plastyczne materiały”, stanowiące zaproszenie dla zwiedzających, aby konstruowali własne i subiektywne wizje przeszłości, oparte na ich dotychczasowym bagażu doświadczeń i odniesień.

Natomiast w rozdziale „Symetryczna archeologia naturo-kultury” (rozdz. 10) Autorka pisze o dwóch językach przeszłości, mianowicie archeologii i archeometrii, wyrażając życzenie, aby dyscyplina dążyła do stworzenia jednego interdyscyplinarnego języka, w którym opowiadać będzie o przeszłości. Swoje rozważania sytuuje w kontekście symetrycznych relacji między ludźmi, zwierzętami, roślinami i materią nieożywioną, kładąc jednocześnie nacisk na tworzenie włączających i horyzontalnych modeli wiedzy. Zdaniem Autorki zbliżenie dwóch języków pozwoliłoby archeologii na angażowanie się w istotne problemy współczesności, a także zrewidowanie swojego aktualnego wizerunek. Archeologia, oparta na symetrycznych relacjach, pozwoliłaby również na zaistnienie muzeum archeologicznego jako „muzeum życia”.

\section{NAPRZÓD, KU PRZYSZLOŚCI!}

(1) Książka Moniki Stobieckiej jest dziełem nowatorskim, które nie ma w literaturze polskiej, lecz także i zagranicznej swego odpowiednika. Wypełnia ona zauważalną lukę w debatach dotyczących współczesnego muzealnictwa archeologicznego, wynikającą z braku rozbudowanej refleksji, zwłaszcza w rodzimym piśmiennictwie 
archeologicznym, dotyczącej wystawiennictwa archeologicznego, ale i krytycznej refleksji nad istotą eksponatu archeologicznego wobec odczuwalnych współcześnie przeobrażeń dyscypliny, co skutkuje pewną stagnacją w muzealnictwie archeologicznym (s. 101). Nowatorski charakter publikacji upatrywać można na wielu poziomach, począwszy od jej opublikowania w serii wydawniczej „Nowa Humanistyka”, wydawanej przy Instytucie Badań Literackich PAN w Warszawie, co sugeruje, że w założeniu praca dotyczy zagadnień do tej pory niepodejmowanych i jej intencją jest rzucenie nowego światła, nowego spojrzenia i perspektyw. Taka też w istocie jest ta pozycja oryginalna i pionierska, proponująca czytelnikom nowe pomysły, sposób myślenia i działania przez odwoływanie się i nawiązywanie do inspiracji teoretycznych współczesnej humanistyki, w tym archeologii, przez propozycję autorskich projektów czy proponowania strategii dla muzeów archeologicznych, o czym poniżej.

(2) Natura artefaktu, kultura eksponatu nie jest jedynie propozycją analizy czy interpretacji określonego fenomenu archeologicznego (w tym przypadku wystawiennictwa), lecz przyświeca jej bardziej wzniosły cel. Wynika on z pragmatycznego przeświadczenia, że dzisiejsza archeologia, stanowiąca element współczesnego świata, w który jest zakotwiczona i z którym pozostaje w dialektycznej relacji, musi się ustawicznie zmieniać. Nie po to jednak, aby realizować potrzebę uzasadnienia swej społecznej użyteczności czy uświadamiać odnośnie charakteru i wagi prowadzonych przez siebie studiów, choć elementy te są bardzo istotne. Książka w swoim inicjalnym założeniu zaprojektowana została jako otwarcie, i jako:

zaproszenie do projektowania i dyskutowania krytycznego muzeum archeologicznego na przyszłość, którego szansy upatruję w muzealnym „zwrocie teoretycznym” ku akademii, podejmowaniu uniwersalnie ważnych problemów na ekspozycjach, a przede wszystkim pobudzeniu archeologicznej wyobraźni. (s. 41)

Jest to założenie ambitne, które w mojej opinii udało się Autorce w satysfakcjonujący sposób zrealizować.

(3) Monika Stobiecka w swojej publikacji, stanowiącej swego rodzaju „emanację najnowszych trendów teoretycznych opartych na kształtujących współczesną humanistykę koncepcjach" (s. 296), korzysta z bogactwa instrumentarium pojęciowego współczesnych nauk humanistycznych. Jak zaznacza Autorka:

[k]siążka jest osadzona w horyzoncie zwrotu ontologicznego w humanistyce i blisko założeń nowego materializmu. Prezentowane tu rozważania lokuję w obszarze aktualnych toczonych $\mathrm{w}$ archeologii i studiach muzealnych debat na temat materii i materialności, i próbuję włączyć się w dyskusje stymulowane przez zwrot ku rzeczom i zwrot materialny. (s. 34)

Na zaprezentowane w książce rozważania duży wpływ wywarły przede wszystkim prądy nowej humanistyki, mianowicie filozofa i socjologa wiedzy Bruno Latoura, realizm spekulatywny Grahama Harmana, sprawczy realizm Karen Barad czy filozofia nowego materializmu Jane Bennett. Swe piętno odcisnęły także inspiracje 
filozofią Martina Heideggera, współczesna muzeologia (m.in. publikacje Susan Pearce czy Eilean Hooper-Greenhill) czy wreszcie idee zaczerpnięte z dorobku Ewy Domańskiej, poznańskiej teoretyczki historiografii i metodolożki nauk humanistycznych (nota bene współpromotorki, wraz z Marią Poprzęcką, dysertacji doktorskiej autorki). Odwołuje się także i nawiązuje do współczesnej, bogatej i różnorodnej refleksji teoretycznej rozwijanej przez archeologów - m.in. Rodneya Harrisona, Michaela Shanksa, Iana Hoddera, Bjørnara Olsena, Afredo González-Ruibala, Christophera Wittmore, Corneliusa Holtorfa czy Gavina Lucasa. Lista inspiracji jest zresztą o wiele dłuższa (co widać choćby po obszernej bibliografii, w jaką opatrzona została publikacja), lecz niemożliwa do przywołania $\mathrm{z}$ racji charakteru niniejszego tekstu.

Niewątpliwym atutem i wartością książki jest nie tylko odwoływanie się przez Autorkę do aktualnych tendencji i nurtów współczesnej humanistyki, lecz ich praktyczna aplikacja i odniesienie do realiów i materii archeologicznej. Mimo że nawiązuje ona do nurtów teoretycznych w archeologii, ponieważ, jak już wspominałem, jedną z ambicji jej pracy jest chęć ukazania relacji między wystawiennictwem archeologicznym a paradygmatami w archeologii, praca wpisuje się w nowy i niezwykle dynamiczny etap w rozwoju myśli archeologicznej, mianowicie etap postparadygmatyczny. Charakteryzuje go pojawienie się nowych ujęć zjawisk i procesów pradziejowych, które nie przyjmują postaci zwartych paradygmatów, lecz teoretycznie podbudowanych konceptualizacji wybranych zagadnień (Marciniak, 2012, s. 30). Taka też właśnie jest publikacja Moniki Stobieckiej - mozaikowa i heterogeniczna w swej naturze.

(4) Jest to bez wątpienia praca charakteryzująca się dużą erudycją. Przejawia się ona nie tylko przez sięganie do różnych odniesień i inspiracji teoretycznych, z którymi Autorka konstruktywnie dyskutuje, lecz także w proponowaniu nowych pojęć, służących jej do interpretacji analizowanych fenomenów i zjawisk. Są to przykładowo: „,kaprys muzealny” (rozdz. 4.3), ,,archeologiczna proteza” (rozdz. 7.3), „kinestetyczny substytut” (rozdz. 7.4) czy „cyfrowy eskapizm” (rozdz. 8.3). W tym przypadku erudycyjność nie sprowadza się więc do rozumienia jej jako pewnej sumy wiadomości czy nabycia wiedzy o charakterze praktycznym, ale przyświeca jej zgoła odmienny cel, ponieważ stanowi ona punkt wyjścia do wnikliwej refleksji nad kondycją współczesnego wystawiennictwa archeologicznego. Co warto podkreślić, mimo że Autorka niejednokrotnie podejmuje sporne kwestie, w swoich opiniach jest wyważona, unikająca jednoznacznych osądów. Jest to w mojej opinii bardzo cenna umiejętność, ponieważ dysponując możliwością oceny pewnych zjawisk z perspektywy nowych ujęć czy dystansu czasowego, nietrudno ulec pokusie krytyki tego, co już nieaktualne. Autorka zresztą zdaje sobie sprawę z czasowości i warunkowości swoich własnych propozycji oraz możliwości ich zdezaktualizowania się w świetle nowszych, odmiennych tendencji, co jest wyraźnie czytelne, choćby przez sformułowania opisujące jej własne podejście jako „projekt”, „propozycję” czy „zaproszenie do dyskusji”. Świadczy to moim zdaniem o jej dojrzałości badawczej, a także samorefleksyjnym i samokrytycznym podejściu do własnych analiz i badań.

(5) Natura artefaktu, kultura eksponatu jest pracą przekraczającą horyzonty. Wymógł to poniekąd sam heterogeniczny przedmiot badań, jakim jest artefakt-jako-eks- 
ponat, który siłą rzeczy „wymusza eklektyzm metodologiczny i skłania do zestawienia ze sobą często skrajnie różnych i odległych teorii i podejść" (s. 24). Przekraczania horyzontów upatruję ponadto $\mathrm{w}$ proponowanych $\mathrm{w}$ jej pracy tropach interpretacyjnych, wykorzystywanych w prowadzonych analizach, próbie redefiniowania tradycyjnych pojęć (artefakt, eksponat) i ukazywania ich odmiennych znaczeń czy przekraczaniu binaryzmów (np. natura - kultura na rzecz naturo-kultury). Wynika to również z obranej $\mathrm{w}$ pracy interdyscyplinarności, stanowiącej naturalne następstwo wykształcenia samej Autorki, będącej zarówno archeolożką, jak i historyczką sztuki i podjętej przez nią próbie prowadzenia badań $\mathrm{w}$ dwóch językach - humanistyki i nauk ścisłych (s. 36). Jej praca wpisuje się tym samym w projekt krytycznych studiów nad dziedzictwem (critical heritage studies) oraz aktualne tendencje do interdyscyplinarnego prowadzenia badań - rozszerzającego horyzonty, umożliwiającego bardziej kompleksowe analizy i spojrzenie na przedmiot badań i interpretacji archeologów.

(6) Książka Moniki Stobieckiej skłania czytelnika do refleksji na wielu płaszczyznach: nad istotą materii archeologicznej - źródłami archeologicznymi, stanowiącymi podstawę badań archeologii, niezależnie od opcji teoretycznej, w horyzoncie której jest ona uprawiana, nad ontologią artefaktu czy nad uwarunkowaniami praktyki dyscyplinarnej archeologii, w tym głównie sposobami rekonstruowania przeszłości i upowszechniania wiedzy o niej. Choć Autorka w swych rozważaniach nie nawiązuje bezpośrednio do nurtów określanych jako archeologia publiczna czy archeologia wspólnotowa, jej praca $\mathrm{w}$ wielu miejscach wykazuje zbieżność z postulatami proponowanymi na ich gruncie. Jest to również publikacja odwołująca się do „archeologicznej wyobraźni”, by użyć słów Michaela Shanksa (2012), którego praca stanowiła dla niej ważną inspirację. Shanks widzi w niej rodzaj twórczej pracy archeologów nad pozostałościami przeszłości lub „wrażliwości rozproszonej przez kulturowy odbiór przeszłości” (Shanks, 2012, s. 15). Wskazuje przy tym na szczególną rolę archeologów, jako tych, którzy za pomocą kreatywnej, archeologicznej wyobraźni „odtwarzają świat znajdujący się za ruinami” i „,wskrzeszają” ludzi z przeszłości. Wyobraźnia archeologiczna, będąca zanurzona w licznych dyskursach kulturowych, predyspozycjach czy instytucjach ,jest zakorzeniona we wrażliwości, wszechobecnym zbiorze postaw wobec śladów i pozostałości, wobec pamięci, czasu i doczesności" (Shanks, 2015, s. 25).

\section{HOLD YOUR HORSES}

Publikacja Moniki Stobieckiej nie jest jednakże pozbawiona kontrowersji i moim odczuciu pewnych - jak sądzę - niezamierzonych niedociągnięć. Ich przyczyny (arché) upatruję w zbyt silnym i jednostronnym miejscami skupieniu się na aktualnie „modnych” prądach teoretycznych w ramach nowej humanistyki, wypracowanych głównie w środowisku anglosaskich badaczy, które z powodzeniem są aplikowane we współczesnym dyskursie archeologicznym, bez pochylenia się nad wcześniejszymi ideami, propozycjami i publikacjami, w tym również nad polskim piśmiennictwem. 
Co prawda, nie można aktualnie przydać im miana nowatorskich (choć w czasie ich pojawienia się takie były, stanowiąc niejednokrotnie kamienie milowe w historii rozwoju myśli archeologicznej), jednak zawierają one nadal aktualne i ważne wskazania.

(1) Autorka, co prawda, przywołuje (s. 54) ważną publikację amerykańskiego archeologa Michaela Briana Schiffera, twórcy archeologii behawioralnej i jego propozycję konceptualizacji procesów formacyjnych - źródłotwórczych, które odnoszą się do mechanizmów wyłączania ze sfery użytkowania materialnych korelatów ludzkiego działania i przechodzenia ich do ziemi w formę zabytkową. Szerzej ich jednak nie eksploruje. Zaproponowany przez nią model 1: „Artefakt: interwencje i zatory” (s. 96) w wielu miejscach odnosi się jednak bezpośrednio do kwestii, o których pisał Schiffer. Kwestie te zostały także szeroko omówione przez Przemysława Urbańczyka (1986), opisującego transformacje ilościowe, przestrzenne, czasowe i relacyjne, mające wpływ na to, jak przedmiot (artefakt) staje się źródłem archeologicznym. Urbańczyk wskazywał nie tylko na rolę czynników natury kulturowej, ale i środowiskowej (procesy podepozycyjne), które prowadzą do zniekształceń czy całkowitego zaniku artefaktów i mają wpływ na stan zachowania się nie tylko warstw archeologicznych, lecz - co istotne - zawartych w nich artefaktów. W tym kontekście refleksję i wnioski zapewne wzbogaciłoby też odniesienie się do wypracowanej przez Stanisława Tabaczyńskiego (1987) konceptualizacji procesu badawczego w archeologii, na który składają się trzy połączone ze sobą elementy składowe: proces systemowy (społeczno-kulturowy), proces źródłotwórczy (stratyfikacyjny) oraz proces badawczy (odkrywczy). Pominięcie przez Autorkę tego nurtu badań, mającego długą i bogatą tradycję, należy uznać za niedopatrzenie.

(2) Podobne uwagi można zgłosić do formuły zintegrowanej interdyscyplinarnej koncepcji badań archeologicznych, obejmującej nauki humanistyczne i społeczne (archeologia, antropologia kulturowa, historia) oraz nauki przyrodnicze (biologia, etologia, antropologia fizyczna), którą postuluje w swej pracy Autorka. Idea ta była szczególnie bliska zmarłemu niedawno profesorowi Stanisławowi Tabaczyńskiemu, czego wyraz dawał w licznych publikacjach, m.in. w wydanej w 1987 r. pracy Archeologia średniowieczna. Zaprezentował w niej spójną koncepcję badań archeologicznych, ze szczegółowym omówieniem ich etapów, podkreślając interdyscyplinarność oraz konieczność integracji w archeologii nowych technik i metod badawczych. Spójność i kompleksowość propozycji S. Tabaczyńskiego pozwala na zasadne jej wykorzystanie także do badań nad innymi okresami chronologicznymi czy w rozwiązywaniu problemów badawczych archeologii. Dowodem tego jest znana Autorce, bo cytowana przez nią, praca, której był on inicjatorem i współredaktorem, mianowicie Przeszłość spoleczna. Próba konceptualizacji (2012). O ile nie są to podejścia inspirowane nowszymi trendami, pokazują niemniej, że pewne drogi zostały już wytyczone, archeolodzy sukcesywnie podążają nimi od lat i można z nich czerpać inspiracje, kierunkować swoje podejście badawcze i spojrzenie na praktykę uprawiania dyscypliny.

(3) Moje wątpliwości rodzi także pewna nieścisłość w zastosowaniu określenia paradygmat w odniesieniu do analizy muzeum Johna Soane'a w Londynie, które zdaniem Autorki ukazuje sposób, w jakim myślano o archeologii w jej dobie przed- 
naukowej. Zgodnie zaś z rozumieniem Thomasa Kuhna (2001) paradygmat to zbiór pojęć i teorii tworzących podstawy danej nauki. Kuhn rozumie paradygmat jako spójny zbiór przekonań dotyczących zasad funkcjonowania świata, korpus pojęć i kategorii go konstytuujących, konceptualizacje mechanizmów jego dynamiki oraz hierarchię problemów badawczych wraz ze sposobami ich rozwiązania, formułowanie praw i prawidłowości oraz procedur uzasadniania powstałej wiedzy (Marciniak, 2012, s. 29-30). Etap przednaukowy archeologii - zainteresowanie starożytnościami i kolekcjonerstwo - nie może być więc rozumiany jako etap paradygmatyczny, skoro $\mathrm{w}$ tym okresie nie istniała jeszcze archeologia jako dyscyplina naukowa. Był to bowiem etap przednaukowy, a więc przedparadygmatyczny ${ }^{1}$ (zob. Trigger, 2006, s. 6).

(4) Odnosząc się do analizowanych w pracy strategii wystawienniczych i dyskursu współczesnej muzeologii, można także wskazać na luki wynikające z nieuwzględnienia pewnych koncepcji i zagadnień czy dorobku polskich badaczy w zakresie problematyki adresowanej w książce. Z pominiętych przez Autorkę prac mam na myśli choćby pracę Doroty Folgi-Januszewskiej (2015), w której odnosi się ona do języka wypowiedzi muzealnej, wirtualności, upubliczniania zbiorów czy choćby koncepcji tzw. neuromuzeologii; publikację Mirosława Borusewicza (2012), która z perspektywy nowej muzeologii podejmuje takie zagadnienia, jak obiekt muzealny i jego kontekst w muzeum czy diagnozuje kierunki rozwoju muzeów w Europie i w Polsce, czy książkę Elżbiety Nieroby (2016), która mierzy się z procesem wykuwania się adekwatnego do nowych okoliczności społecznych modelu muzeum, analizując możliwości implementacji nowych praktyk w przestrzeni muzeum. Ze starszych pozycji wspomnieć należy szereg publikacji poświęconych analizom wystawiennictwa muzealnego i ekspozycji muzealnych Jerzego Świecimskiego (1976, 1996, 1997, 1998), fundamentalną w mojej opinii pozycję Wojciecha Gluzińskiego U podstaw muzeologii (1980), zawierającą pogłębioną i niezwykle inspirującą refleksję dotyczącą pojęcia przedmiotu muzealnego czy kwestii autentyczności i oryginalności, czy wreszcie pracę Sylwestra Czopka (2000) dedykowaną muzealnictwu archeologicznemu.

Jak tłumaczy Autorka, z powodu ogromu literatury zmuszona była do jej ograniczenia i „selekcji materiału teoretycznego i empirycznego" (s. 27), co jest dla mnie kwestią niepodlegającą dyskusji. Każda bowiem praca naukowa polega na konieczności selekcjonowania i wyboru pewnych elementów przy pomijaniu innych, nieistotnych z punktu widzenia celów postawionych w pracy. W tym kontekście za uzasadnione należy uznać celowe pominięcie takich zagadnień, jak archeologiczna edukacja muzealna (zob. np. Pawleta, 2016, s. 366-378), ponieważ próba uwzględnienia wszystkiego zapewne zakłóciłaby główną oś narracyjną pracy. Rozumiem taki krok, choć jestem odmiennego zdania, ponieważ w mojej opinii włączenie do analiz

\footnotetext{
${ }^{1}$ Co warte podkreślenia, o ile w przypadku archeologii środkowoeuropejskiej, w tym polskiej, zakłada się, że pierwszym naukowym paradygmatem była archeologia kulturowo-historyczna (z fundującymi jej założenia ewolucjonizmem i dyfuzjonizmem), o tyle spojrzenie w kręgu anglosaskim jest odmienne, ponieważ przykładowo C. Renfrew i P. Bahn (2002) za etap paradygmatyczny uważają dopiero archeologię procesualną, zaś etapowi archeologii kulturowo-historycznej przypisują etap nienaukowy.
} 
edukacji muzealnej - stanowiącej współcześnie wszechstronną i bezpośrednią dziedzinę działalności niemal wszystkich instytucji muzealnych jako jeden z zasadniczych elementów ich misji, za pośrednictwem której demonstrują one swoją żywotność jako przestrzeń działania i rozwijania nowych perspektyw i kierunków rozwoju - przyczyniłoby się do ubogacenia i bardziej komplementarnego obudowania refleksji zawartych w pracy. Niemniej pewne pominięte kwestie odnoszą się bezpośrednio do jej problematyki.

Jedną z nich jest zbyt mała uwaga poświęcona jednemu z modus operandi dyskursu muzealnego, mianowicie autentyczności (eksponatów), na temat której istnieje bardzo bogata literatura (m.in. Brenna, Christensen, Hamran, 2019), czy choćby brak odniesienia do koncepcji benjaminowskiej aury (Benjamin, 1996). Są to moim zdaniem kluczowe aspekty, podnoszone także na gruncie nowej muzeologii, w kontekście jej zaniku i kwestionowania przez współczesne tendencje wystawiennicze, w których można doszukiwać się precesji ,archeologicznych protez” (rozdz. 8) czy ucieczki w „,yfrowy eskapizm” (rozdz. 8.3).

Innym elementem jest brak zwrócenia uwagi w kontekście analizowanego przez Autorkę wpływu obowiązujących teorii (paradygmatów) na modelowanie eksponatu czy strategii wystawienniczych (s. 221) na ich pozanaukowe uwarunkowania. Dochodzi tu tym samym do jednostronnego spojrzenia, z pominięciem zewnętrznych determinantów rozwoju nauki, w tym muzealnictwa. Jednakże w obecnym świecie, poddanym przemożnemu wpływowi ekonomii - bardziej chyba niż kiedykolwiek - muzea konfrontowane są z koniecznością dokonywania wyborów o charakterze nie tylko merytorycznym, ale i organizacyjnym oraz finansowym. To głównie ekonomiczne i społeczne uwarunkowania mogą i wpływają na decyzje dotyczące m.in. wyboru spośród dostępnych możliwych do wykorzystania zasobów muzealnych, kierunków i sposobów interpretacji zbiorów opartej na nich narracji muzealnej czy tego, w jaki sposób i w jakiej formie mają one być udostępniane i wystawiane (np. Matt, 2006; Murzyn-Kupisz, 2016).

\section{KONKLUZJE}

Chcę wyraźnie podkreślić, że przedstawione powyżej wątpliwości w niczym nie umniejszają wartości publikacji Moniki Stobieckiej, lecz stanowią odpowiedź na zaproszenie przez nią czytelników do dyskusji z zawartymi w niej tezami. Bez wątpienia zaproponowane przez nią stanowisko jest podejściem wielowymiarowym, otwartym i jednocześnie zakorzenionym w świecie i jego aktualnych kontekstach; jest to praca o pisaniu przeszłości na nowo. Zawiera ona propozycje i tropy pobudzające do krytycznej i inspirującej refleksji. Co istotne, publikacja nie proponuje czytelnikom gotowych odpowiedzi, lecz problematyzuje pewne zagadnienia, dowodząc tym samym możliwości świeżego i jednocześnie płodnego poznawczo spojrzenia na przedmiot badań archeologii i praktykę archeologiczną, w którą często wkrada się nieunikniony automatyzm czy sztampowość. Nie mam wątpliwości, że z racji na swój interdyscy- 
plinarny charakter, jak również ważność podejmowanej problematyki, spotka się ona z zainteresowaniem nie tylko archeologów, ale również historyków sztuki, historyków, muzealników, antropologów, kulturoznawców czy filozofów kultury, jak również licznego grona odbiorców spoza środowiska naukowego. Udowadnia bowiem, że muzeum archeologiczne nie musi być skostniałą instytucją, lecz można spojrzeć na nie w szerszej perspektywie poznawczej. Również współczesna archeologia jawi się w niej jako niezwykle innowacyjna dyscyplina humanistyki, przełamująca bariery, wykraczająca poza horyzonty czasowe i utartą problematykę badawczą, otwarta na współczesny świat i jego problemy.

Bliskie jest mi wyrażone w książce stanowisko, że w przypadku wystawiennictwa muzealnego forma prezentacji powinna być drugorzędna - nowoczesne środki multimedialne, które mają pomagać w komentowaniu wypowiedzi muzealnej, nie zaś dominować przekaz, muszą być stosowane z należytym umiarem, aby nie zgubić eksponatu - obiektu muzealnego. Muzea archeologiczne umożliwiają bezpośrednią relację z autentycznymi zabytkami z przeszłości, w ich przypadku nadal pierwszoplanowy jest i powinien pozostać sam eksponat, oryginalny zabytek. W dobie symulacji, hiperrzeczywistości i nadmiernej wirtualizacji możliwość wejścia w muzeum w bezpośrednią relację z czymś autentycznym, materialnym, realnym stanowi tym samym o ich atucie i jest jednocześnie alternatywą dla wirtualnych światów. Podobnie jak Monika Stobiecka uważam, że muzea archeologiczne stają obecnie przed szansą stania się ważną instytucją komunikacji społecznej oraz aktywnego dialogu, otwartą na bieżące wyzwania społeczne i w tym kierunku powinny dalej ewoluować.

Jednakże nie ze wszystkimi zawartymi w książce propozycjami się zgadzam i nie wszystkie uważam za wykonalne. Wpisana w nią choćby - w zgodzie z założeniami programowymi nowego materializmu (np. Domańska, 2008; Olsen, 2013) - konieczność dążenia do zrzucenia brzemienia naszej kultury i odrzucenie kultury zachodniej, tęsknota za rzeczywistością czy nostalgia za mitycznym porządkiem kultury jest w moim odczuciu trudne do osiągnięcia, a nawet nierealne. Zakłada ono bowiem istnienie rzeczywistości obiektywnej w stosunku do poznającego ją podmiotu i niezależnej od aktów świadomości. Tymczasem, nie zaprzeczając temu, że przeszłość istniała na sposób realny, podobnie jak z przekonaniem, że świat zewnętrzny istnieje, problemem jest to, że nie istnieje jakikolwiek zewnętrzny opis tego świata, tak jak nie istnieje zewnętrzny opis przeszłości (Mamzer, 2010, s. 233). Konsekwentnie badacz przeszłości nie ma nigdy do czynienia z przeszłą rzeczywistością, lecz z myśleniem, mówieniem czy pisaniem o niej, czyli z językiem, co przeczy tezom rzeczników „powrotu do materialności", który niekiedy traktowany jest jako powrót do samej istoty czy do źródłowych początków, które wyprzedzają to, co zostało na nich językowo nadbudowane. Niemożliwe jest więc przedstawianie przeszłości na sposób „czysto” fizykalny, przez obiektywnie istniejące przedmioty, ponieważ są one zawsze kulturowo postrzegane i konstruowane. Zatem to nie przedmioty mówią nam o przeszłości, lecz my o niej mówimy, z punktu widzenia kultury, w której funkcjonujemy i której jesteśmy częścią (Mamzer, 2021). Konsekwentnie jestem również sceptyczny wobec postulowanej w książce możliwości, a nawet konieczności zbliżenia czy wręcz połą- 
czenia przyrodoznawstwa i humanistyki, a co za tym idzie stosowania w tej ostatniej tych samych metod badawczych, co w przyrodoznawstwie, $\mathrm{z}$ racji nieprzystawalności tychże dwóch dyskursów.

Niewątpliwie przez tradycyjnie nastawionych archeologów książka może zostać odebrana jako pozycja miejscami przeteoretyzowana czy o potencjalnie niewielkim przełożeniu na praktykę współczesnej archeologii i wystawiennictwo archeologiczne. Sprzeciw mogą budzić konsekwencje zawartych w niej sugestii i wskazań dotyczących przykładowo zaniechania dobrze ugruntowanego $\mathrm{w}$ archeologii podziału na artefakty i ekofakty, stwierdzenia, że ,,artefakt nie jest przedmiotem” (s. 95) czy konieczność przesunięcia akcentu z człowieka jako siły sprawczej w tworzeniu przedmiotów (a tym samym odejścia od ujmowania archeologii jako dziejów człowieka) na rzecz sił sprawczych natury, zawartych w propozycjach wysuwanych na gruncie archeologii nieantropocentrycznej.

Konkludując, w projekt Moniki Stobieckiej wpisana jest pewna doza idealizmu wyrażającego się niezgodą na otaczający nas świat i kierunek, w którym on zmierza, utratę wrażliwości na świat przyrody, o którym niewiele wiemy, a także świat ludzkich nierówności. Wyraża to zresztą dość jasno, czego przykładem może być poniższy cytat, będący jej odpowiedzią na retoryczne pytanie, jakiego rodzaju dziedzictwo pozostawimy po sobie potomnym:

czy tego rodzaju artefakty, związane z degradacją, zniszczeniem, brakiem szacunku dla środowiska, mają stać się naszą spuścizną dla potomności? [...] Czy właśnie tak chcemy zapisać się na kartach planetarnej historii? (s. 302)

Monika Stobiecka chce, aby właśnie archeologia miała wpływ na nasze praktyki życia codziennego, budowanie pomostów między nami a naszymi przodkami, budowanie w nas wrażliwości. Jej projektowi „muzeum życia” (rozdz. 10.3) towarzyszy jednocześnie wiara w „lepszy” świat, oparty na równych prawach, relacyjny, uważny, w którym istnieje poszanowanie wielości i różnorodności. We wpisanym w to idealizmie paradoksalnie tkwi jego siła i sprawczość, która może kiedyś doprowadzi do tego, że muzeum archeologiczne - „muzeum życia” stanie się instytucją, która te wzniosłe idee urzeczywistni.

\section{BIBLIOGRAFIA}

Benjamin, W.

1996 Dzieło sztuki w dobie reprodukcji technicznej. W: W. Benjamin, Anioł historii: eseje, szkice, fragmenty (s. 201-239). Poznań: Wydawnictwo Poznańskie.

Borusewicz, M.

2012 Nauka czy rozrywka. Nowa muzeologia w europejskich definicjach muzeum. Kraków: Universitas.

Brenna, B., Christensen, H. D., Hamran, O. (red.)

2019 Museums as Cultures of Copies. The Crafting of Artefacts and Authenticity. New YorkLondon: Routledge. 
Czopek, S.

2000 Wstęp do muzealnictwa i konserwatorstwa archeologicznego. Rzeszów: Wydawnictwo Wyższej Szkoły Pedagogicznej.

Domańska, E.

2008 Problem rzeczy we współczesnej archeologii. W: J. Kowalewski, W. Piasek (red), Rzeczy i ludzie. Humanistyka wobec materialności (s. 27-60). Olsztyn: Wydawnictwo Instytutu Filozofii UWM.

Folga-Januszewska, D.

2015 Muzeum: fenomeny i problemy. Kraków: Universitas.

Gluziński, W.

1980 U podstaw muzeologii. Warszawa: Państwowe Wydawnictwo Naukowe.

Kuhn, T.

2001 Struktura rewolucji naukowych. Warszawa: Fundacja Aletheia.

Mamzer, $\mathrm{H}$.

2010 Źródła archeologiczne: Artefakty czy językowe o nich wypowiedzi? Humanistyka i Przyrodoznawstwo, 16, 227-250.

2021 Jak czlowiek konstruowat świat i siebie samego. Archeologia w procesie humanizacji świata. Poznań: Instytut Archeologii i Etnologii PAN (w druku).

Marciniak, A.

2012 Paradygmaty badawcze w archeologii. W: S. Tabaczyński, A. Marciniak, D. Cyngot, A. Zalewska (red.), Przeszłość społeczna. Próba konceptualizacji (s. 29-83). Poznań: Wydawnictwo Poznańskie.

Matt, G.

2006 Muzeum jako przedsiębiorstwo. Latwo i przystępnie o zarzadzaniu instytucja kultury. Warszawa: Fundacja Aletheia.

Murzyn-Kupisz, M.

2016 Instytucje muzealne z perspektywy ekonomii kultury. Kraków: Universitas.

Nieroba, E.

2016 Pomiędzy dobrem wspólnym a elitarnościa. Wspótczesny model muzeum. Opole: Wydawnictwo Uniwersytetu Opolskiego.

Olsen, B.

2013 W obronie rzeczy. Archeologia i antropologia przedmiotów. Warszawa: Wydawnictwo IBL PAN.

Pawleta, M.

2016 Przeszłość we wspótczesności. Studium metodologiczne archeologicznie kreowanej przeszłości w przestrzeni społecznej. Poznań: Wydawnictwo Naukowe UAM.

Renfrew, C., Bahn, P.

2002 Archeologia: teorie, metody, praktyka. Warszawa: Prószyński i S-ka.

Shanks, M.

2012 The Archaeological Imagination. Walnut Creek: Left Coast Press.

Stobiecka, M.

2020 Natura artefaktu, kultura eksponatu. Projekt krytycznego muzeum archeologicznego. Warszawa: Instytut Badań Literackich.

Świecimski, J.

1976 Ekspozycja muzealna jako utwór architektoniczno-plastyczny (podstawy teoretyczne ekspozycji naukowych w muzeach). Kraków: UJ.

1996 Dydaktyzm w wystawach muzealnych, cz. 1: Wystawy teatropokrewne. Muzealnictwo, $38,25-32$.

1997 Dydaktyzm w wystawach muzealnych, cz. 2: Wystawy narracyjne. Muzealnictwo, 39, $80-87$.

1998 Ekspozycja muzealna - jej wartość informacyjna i artystyczna. Muzealnictwo, 40, 97-110. 
Tabaczyński, S.

1987 Archeologia średniowieczna: problemy, źródla, metody, cele badawcze. Warszawa: Zakład Narodowy im. Ossolińskich, Wydawnictwo Polskiej Akademii Nauk.

Tabaczyński, S., Marciniak, A., Cyngot, D., Zalewska, A. (red.)

2012 Przeszłość spoleczna. Próba konceptualizacji. Poznań: Wydawnictwo Poznańskie.

Trigger, B.

2006 A History of Archaeological Though. Second Edition. Cambridge: Cambridge University Press.

Urbańczyk, P.

1986 Formowanie się układów stratyfikacyjnych jako proces źródłotwórczy. W: W. Hensel, G. Donato, S. Tabaczyński (red.), Teoria i praktyka badań archeologicznych. Przesłanki metodologiczne (s. 184-245). Wrocław: Ossolineum.

\author{
WHAT IS THE FUTURE OF ARCHAEOLOGICAL MUSEUM? \\ A DISCUSSION WITH THESES PRESENTED IN A BOOK BY MONIKA STOBIECKA: \\ NATURA ARTEFAKTU, KULTURA EKSPONATU. \\ PROJEKT KRYTYCZNEGO MUZEUM ARCHEOLOGICZNEGO
}

\title{
Su m m ary
}

In the article, I polemically and critically discuss with the theses included in the recently published publication by Monika Stobiecka - Natura artefaktu, kultura eksponatu. Projekt krytycznego muzeum archeologicznego (Stobiecka, 2020). The authoress offers a critical reflection on the subject of archeological research, and the theory and practice of archeology. She shows archeology as an innovative science striving for interdisciplinarity, extending beyond traditional research issues, open to the modern world. At the same time, the authoress postulates the need to reorient archeology to take the form of a symmetrical and relational discipline that integrates the humanistic and archeometric approach in its practice and interpretation of the past. In the book the need to create a new type of archaeological museum - namely the critical museum and the "museum of life" is suggested.

The book is interdisciplinary, placed at the borders between the history and theory of archeology, art history and museum studies. The considerations included in it focus on three concepts that link them together: artifact, exhibit and museum strategies, in order to show the translation of an artifact into an exhibit using the theory and methodology of archeology. Taking the institution of an archaeological museum as an example, the authoress proposes a project of a critical museum, aimed at a critical institution that opens up to intellectual modernity, mediates various theories, in other words a museum in which there is the indissolubility of scientific institutions and scientific discourses and which illustrates paradigmatic changes in theories and negotiates their meanings. In order to achieve the goal set in the book, the authoress successfully applies the assumptions of the so-called the New Museology and its current translation into the reality of an archaeological museum. Thus, it indicates that one of the main goals of an archaeological museum should be precisely to achieve the status of a critical museum, i.e., to introduce into its space such exhibition narratives that, on the one hand, would be able to face the current challenges of the present, and on the other hand, present the latest research trends in archeology.

In the following article, I discuss the theses of the book. I indicate, among others that Monika Stobiecka's work is an innovative research that has no counterpart in Polish and foreign language literature. It fills a noticeable gap in debates on contemporary archaeological museology, effecting 
from the lack of extensive reflection, especially in the Polish archaeological literature, on archaeological exhibitions, but also a critical reflection on the essence of an archaeological exhibit in the face of the currently noticeable transformations of the discipline, which results in a certain stagnation in archaeological museology.

Additionally, Monika Stobiecka in her publication, which is a kind of "emanation of the latest theoretical trends based on concepts shaping contemporary humanities" (p. 296), uses the richness of conceptual instruments of contemporary humanities. The undoubted advantage and value of the book is not only the author's reference to current trends and trends in contemporary humanities, but also their practical application and reference to archaeological reality and matter.

It is undoubtedly a work characterized by great erudition. It manifests itself not only by referring to various works and theoretical inspirations with which the authoress discusses constructively, but also by proposing new concepts to interpret the phenomena and phenomena analyzed.

Natura artefaktu, kultura eksponatu is a book that crosses horizons. In a way, this required the very heterogeneous subject of research, which is the artifact-as-exhibit, which inevitably "forces methodological eclecticism and prompts the juxtaposition of often extremely different and distant theories and approaches" (p. 24). I also see the crossing of horizons in the interpretative tropes proposed in her work, used in the conducted analyzes, an attempt to redefine traditional concepts (artifacts, exhibits) and to present their different meanings or transgressing binarisms (e.g., nature vs. culture for the sake of nature-culture). It also results from the interdisciplinarity of this work.

Finally, Monika Stobiecka's book prompts the reader to reflect on many levels: on the essence of archaeological matter - archaeological sources, which constitute the basis of archeology research, regardless of the theoretical option in the horizon of which it is practiced, on the ontology of the artifact or on the determinants of disciplinary practice of archeology, mainly ways of reconstructing the past and disseminating knowledge about it. 
